\title{
Henry Kissinger's Negotiation Campaign to End the Vietnam War
}

\section{Citation}

Sebenius, James K., and Eugene B. Kogan. "Henry Kissinger's Negotiation Campaign to End the Vietnam War." Harvard Business School Working Paper, No. 17-053, December 2016.

\section{Permanent link}

http://nrs.harvard.edu/urn-3:HUL.InstRepos:30011595

\section{Terms of Use}

This article was downloaded from Harvard University's DASH repository, and is made available under the terms and conditions applicable to Open Access Policy Articles, as set forth at http:// nrs.harvard.edu/urn-3:HUL.InstRepos:dash.current.terms-of-use\#OAP

\section{Share Your Story}

The Harvard community has made this article openly available.

Please share how this access benefits you. Submit a story.

\section{Accessibility}




\section{Henry Kissinger's Negotiation Campaign to End the Vietnam War}

James K. Sebenius

Eugene B. Kogan

Working Paper 17-053 


\title{
Henry Kissinger's Negotiation Campaign to End the Vietnam War
}

\author{
James K. Sebenius \\ Harvard Business School \\ Eugene B. Kogan \\ Harvard Business School
}

Working Paper 17-053 


\title{
Henry Kissinger's Negotiation Campaign to End the Vietnam War
}

\author{
James K. Sebenius and Eugene B. Kogan* \\ December 12, 2016, v1.25
}

\begin{abstract}
President Richard M. Nixon was elected in 1968 with the widespread expectation that he would bring about an end to the costly and unpopular war in Vietnam. The task largely fell to National Security Adviser Henry Kissinger. When the negotiations began, North Vietnam appeared to have a winning hand with time on its side. To induce agreement from North Vietnam on acceptable terms, Kissinger orchestrated a complex negotiation campaign with multiple fronts: North Vietnam, the U.S. public and Congress China, the USSR, West Germany, and South Vietnam. Kissinger's efforts culminated in the signing of the 1973 Paris Peace Accords, which held for about two years before collapsing in the wake of Watergate. The account in this working paper carefully describes - but does not analyze nor draw lessons from - core features of these challenging negotiations. Forthcoming papers will provide analysis and derive general insights from this negotiation campaign.
\end{abstract}

Keywords: Kissinger, negotiation, negotiation campaign, bargaining, diplomacy, coercive diplomacy, multiparty negotiations, dispute resolution, mediation, international relations

The signing of the Paris Peace Accords, officially called the "Agreement Ending the War and Restoring the Peace in Vietnam," on January 27, 1973 marked a formal end to the agonizing war, which had claimed over 58,000 American and roughly 1,000,000 Vietnamese lives, left several hundred thousand Americans wounded, and deeply divided American society. ${ }^{1}$

Two series of separate negotiations - one public, one secret-focused on ending the Vietnam War. The public sessions were attended by representatives of four parties: (1) the United States, (2) North Vietnam, (3) South Vietnam, and (4) the National Front for the Liberation of the South (or Vietcong). ${ }^{2}$ These sessions convened for the first time in January 1969. ${ }^{3}$ The signing of the Paris Peace Accords was one of the few productive sessions of these public peace talks; the previous 174 plenary meetings yielded virtually no results. ${ }^{4}$

In parallel with these public talks, secret negotiations commenced in Paris, starting in February 1970. U.S. National Security Adviser Henry Kissinger and North Vietnamese Politburo member Le Duc Tho served as the dominant negotiators. ${ }^{5}$ These secret negotiations ultimately produced the substantive breakthroughs that led to the Paris Peace Accords. (See Table 1 for a schematic of the public and secret talks.)

\footnotetext{
* James K. Sebenius (jsebenius@hbs.edu) is the Gordon Donaldson Professor of Business Administration at Harvard Business School. Eugene B. Kogan (eugene_kogan@hks.harvard.edu) is Research Director of the American Secretaries of State Project. Thanks to Marton Kis-Dornyei for help with the bibliography.
}

Copyright 2016 ㄷ James K. Sebenius 


\section{Table 1: Party Map--Paris Negotiations \\ Public Negotiations (May 1968 to January 1973)}

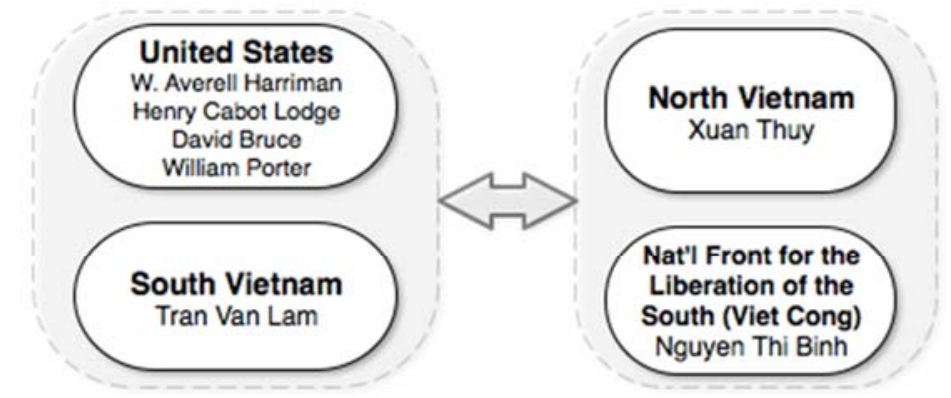

\section{Secret Negotiations (February 1970 to January 1973)}

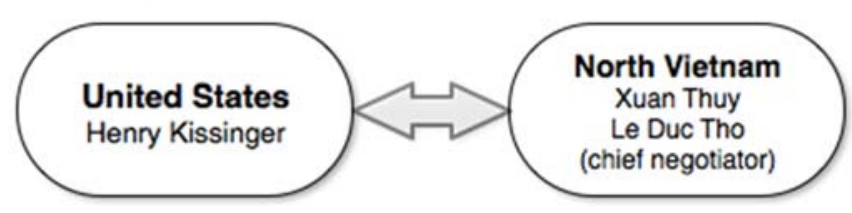

Along with President Nixon, Kissinger confronted three broad challenges as he led a "negotiation campaign" to achieve an acceptable outcome to the Vietnam War. ${ }^{6}$ First, he had to overcome unrelenting military efforts by the North Vietnamese to vanquish South Vietnam and persuade that party that genuine negotiations were in its interest. Second, he sought to respond to increasingly insistent pressure from Congress and domestic anti-war protesters to withdraw entirely from Indochina. ${ }^{7}$ Third, for any agreement short of the military victory the South Vietnamese fervently pursued, Kissinger would have to persuade a most reluctant South Vietnamese President Thieu to accept it.

\section{From Truman to Johnson}

Occupied by Japan during the Second World War, Indochina was a French colony of some 42 million people. With post-war Vietnam back under French rule, communist guerillas waged an anti-colonial struggle for independence with support from Communist China. ${ }^{8}$

After the onset of the Korean War in 1950 and following what came to be known as "domino theory," President Harry Truman began aiding France in the war in Indochina. In the context of the Cold War, this theory suggested that once one country fell under Communist control, other Communist "dominoes" in the region would follow. The strategic implication was that the spread of Communist influence had to be resisted even in areas that did not otherwise have significant strategic importance to the United States. Following its defeat at Dien Bien Phu, France withdrew from Vietnam upon the signing of the July 20, 1954 Geneva Accords, which divided Vietnam at the 17th parallel. ${ }^{9}$ In October 1955, Ngo Dinh Diem was elected President of South Vietnam. The United States recognized South Vietnam and by the end of the Eisenhower Administration had provided over $\$ 1$ billion in assistance, with 692 U.S. military advisors helping train the South Vietnamese Army. ${ }^{10}$ Seeking to contain the spread of communism - by then, the guiding principle of U.S. foreign policy-President John F. Kennedy increased the U.S. presence in Vietnam from 900 to 16,263 military advisors. ${ }^{11}$ By 1963, Diem was deposed and killed in a U.S.-condoned coup. ${ }^{12}$ General Nguyen Van Thieu, one of the coup leaders, became President of South Vietnam in 1967.13 
Following John F. Kennedy's assassination, Lyndon Johnson was elected President in 1964 with the largest popular vote in U.S. history. In August 1964 Congress passed the Gulf of Tonkin Resolution, which later became quite controversial, authorizing President Johnson to use force to restore peace in Indochina. ${ }^{14}$

Although the U.S. public and policymaking community had generally regarded Communist countries as monolithic during the 1950s and 60s, relations between the USSR and China became increasingly tense through the 1960s. ${ }^{15}$ The "Sino-Soviet split" worked mostly in Hanoi's favor as the Soviet Union and China competed for the position of North Vietnam's primary supporter. ${ }^{16}$ For a decade after the French defeat in 1954, China provided Hanoi with $\$ 670$ million of aid, and increased support from $\$ 110$ million in 1965 to $\$ 225$ million in 1967. China's aid averaged between $\$ 150$ and \$200 million per year during the remaining years of the war. ${ }^{17}$

Chinese Premier Mao Zedong personally assured Ho Chi Minh, North Vietnam's leader, of China's support after the August 1964 Gulf of Tonkin resolution. From 1965 to 1969, Beijing sent 320,000 personnel to Vietnam to help operate military equipment and to build and repair transportation links. ${ }^{18}$ The Soviet Union's support-\$365 million-from 1954 to 1964 was more modest than Beijing's, reflecting Soviet General Secretary Nikita Khrushchev's belief that Indochina was a low strategic priority compared to the post-war settlement of Germany and the emerging China challenge. ${ }^{19}$ Leonid Brezhnev's assumption of power in October 1964 marked a change in Moscow's approach. ${ }^{20}$ As the Sino-Soviet split deepened, it became "critically important [for Moscow] to reverse the pro-Chinese trend in Hanoi." 21 Embroiling the United States in a protracted struggle that drained its resources and attention was an added advantage that the Soviet leadership sought to exploit. ${ }^{22}$

In 1965, Hanoi rejected Chinese Premier Zhou Enlai's request that North Vietnam dissociate itself from Moscow, and accepted some $\$ 550$ million-worth of Soviet military assistance. ${ }^{23}$ In 1965, reassured of continued Soviet and Chinese support, Ho Chi Minh launched the offensive against the South Vietnamese city of Pleiku, which marked the beginning of the U.S. war in Vietnam by triggering the U.S. "Rolling Thunder" bombing campaign, arguably authorized by the Gulf of Tonkin Resolution. ${ }^{24}$ The first U.S. combat troops were also deployed to Vietnam that year. ${ }^{25}$ A wave of public anti-war protests greeted the bombing campaign and escalation of the U.S. military role. ${ }^{26}$ Frustrated by his inability to bring the conflict to an end and facing a huge domestic backlash against the war President Johnson announced in March 1968 that he would not seek reelection.

Nixon and Kissinger. Richard Nixon was elected President in 1968 in the widespread expectation that he would end the deeply unpopular war in which almost 550,000 Americans were serving and 35,000 had already died. ${ }^{27}$

On December 20, 1968, the United States expressed readiness to seek a settlement. ${ }^{28}$ The North Vietnamese responded with an ultimatum: all U.S. forces were to leave Vietnam, after the United States forcibly deposed the South Vietnamese government. ${ }^{29}$ As President Nixon's National Security Adviser, Kissinger judged that, if fulfilled, Hanoi's demand to turn on an ally would deal a severe blow to the U.S. credibility worldwide.

In tandem with these opening negotiation moves, Nixon approved Operation Menu-a bombing campaign against North Vietnamese sanctuaries and supply lines in neighboring Cambodia from which Hanoi's attacks were weekly inflicting hundreds of casualties on American soldiers. ${ }^{30}$ Starting on March 18, 1969, B-52s bombed within several miles of Cambodian border. ${ }^{31}$ Kissinger maintained that this bombing took place in in largely unpopulated areas. ${ }^{32}$ Lasting until May 26, 1970, these and similar measures undertaken later were deeply controversial at the time and have remained so for decades. All the criticisms of the Cambodian operations were magnified by the secrecy with which they were allegedly surrounded; Kissinger maintains that appropriate parties were properly informed throughout. ${ }^{33}$ 
At home, Kissinger confronted potent anti-war forces. Numerous public and Congressional critics demanded prompt disengagement from Vietnam in return for the release of the American prisoners of war. On October 15 of that year, massive demonstrations took place around the country -20,000 in New York, 30,000 in New Haven, and 100,000 in Boston. ${ }^{34}$ In 1971 and 1972, Congress passed, respectively, 72 and 35 non-binding resolutions demanding U.S. withdrawal. ${ }^{35}$

Responding to the potent domestic backlash against the war, the Nixon Administration initiated regular troop withdrawals, hoping to keep the public united enough not to actively undercut the military efforts in Vietnam. President Nixon made the first decision to withdraw 25,000 troops on June 7, 1969, followed by 40,500 troops on September 16, 1969, 50,000 on December 15, 1969, and 150,000 on April 20, 1970. More withdrawals followed: 70,000 troops on January 13, 1972 and 12,000 on August 29, 1972, which left 27,000 American soldiers in Vietnam. ${ }^{36}$

Kissinger was convinced that Hanoi would seek to take battlefield advantage of the troop cuts that continually reduced U.S. military presence in Vietnam. He stated: "An enemy determined on protracted struggle could only be brought to compromise by being confronted by insuperable obstacles on the ground." 37 The North Vietnamese would draw out the negotiations while seeking a military victory. ${ }^{38}$ In Nixon and Kissinger's judgment, the only way to keep up the military pressure on Hanoi, while satisfying the domestic demands for troop withdrawal, was to replace the departing troops with air and naval forces that were not included in the total troop numbers. ${ }^{39}$

Kissinger negotiated for the first time with Le Duc Tho during three secret Paris meetings from February 20 to April 4, 1970. During the last of these sessions, Kissinger proposed a mutual U.S.-North Vietnamese withdrawal from South Vietnam within sixteen months. ${ }^{40}$ On September 7, 1970, he went much farther than the April proposal: unlike the previous proposal, the U.S. was now prepared to leave no residual U.S. presence in South Vietnam. ${ }^{41}$ Hanoi was unmoved, continuing to insist on U.S. complicity in effecting regime change in Saigon. ${ }^{42}$

President Nixon's speech to the nation on October 7, 1970 positioned the United States as forthcoming and persistently seeking a negotiated settlement (at the public negotiating sessions, while, for the time being, keeping secret the Kissinger-Le Duc Tho talks), while accusing Hanoi as obstructing peace. ${ }^{43}$ The President offered a cease-fire, including a halt to ongoing bombing, and a negotiation to agree on the timing and mode of U.S. withdrawal. The North Vietnamese quickly turned down the proposal. ${ }^{44}$

The United States now took much more extensive steps to cut off the Vietcong insurgency's supply lines and sanctuaries in neighboring Cambodia and Laos. Hanoi had been using these routes and locations since the late 1950s to supply the Vietcong guerillas and to attack and kill thousands of South Vietnamese and American troops. ${ }^{45}$ The United States invaded North Vietnamese sanctuaries in Cambodia in May 1970 and those in Laos in February and March 1971.

Kissinger regarded the ground invasions of Cambodian and Laotian sanctuaries as strategically necessary to starve the Vietcong insurgency of support and to stop the attacks on American and South Vietnamese soldiers. U.S. anti-war critics, by contrast, condemned these actions as an unprovoked expansion of the war into neutral countries with dire long-term consequences for the region. Such critiques, often virulent, continue to the present day. ${ }^{46}$

They further argue that the Cambodian invasion was militarily pointless and counterproductive by provoking the North Vietnamese into further aggression within Cambodia, undermining the Cambodian government, and eventually resulting in the brutal rule by the Khmer Rouge. ${ }^{47}$ A corollary of this view is that Nixon and Kissinger purposefully misrepresented the efficacy of their Cambodia policy, keeping much of it secret. ${ }^{48}$ 
By contrast, Kissinger believed a key front in the Vietnam War was Cambodia in which the North Vietnamese had been massively involved for years. One of the aims of the Cambodia operation was to signal to the North Vietnamese and its superpower supporters in Moscow and Beijing that the U.S. had the will and capacity to resist Hanoi's aggression by cutting off supplies to the Vietcong guerillas. ${ }^{49}$ "We needed a strategy that made continuation of the war seem less attractive to Hanoi than a settlement," Kissinger reflected. ${ }^{50}$ Kissinger likewise argues that the North Vietnamese expanded their Cambodian operation on their own irrespective of America's actions. ${ }^{51}$

While previous offers envisioned a mutual U.S.-North Vietnamese withdrawal from South Vietnam, on May 31, 1971, Kissinger told Le Duc Tho that the United States was prepared to withdraw unilaterally in return for an end to North Vietnamese infiltration of Cambodia and Laos, which meant leaving the existing Vietcong and regular North Vietnamese formations in the South intact. ${ }^{52}$ Again, Hanoi summarily rejected the offer.

Kissinger soon offered another concession. While in previous meetings he demanded that American prisoners be released before U.S. withdrawal, on August 16 he offered to withdraw U.S. troops at the same time as the prisoners were released as long as this did not involve the United States removing Saigon's government on the way out. ${ }^{53}$ Hanoi rejected the offer.

Foreseeing a major North Vietnamese offensive against the South, Nixon and Kissinger sought to prepare the diplomatic ground for a powerful U.S. military response that they felt was necessary. ${ }^{54}$ To accomplish this, Nixon needed to establish a record of reasonableness in negotiations. In his January 25, 1972 address to the nation, the President for the first time revealed the secret talks between Kissinger and Le Duc Tho. After indicting Hanoi for rejecting the extremely forthcoming American peace proposals, Nixon offered to withdraw U.S. troops within six months. ${ }^{55}$ However, he once again refused to overthrow the government in Saigon. ${ }^{56}$

Kissinger shared the text of Nixon's January 25 speech with Moscow and Beijing, warning that the U.S. patience with North Vietnam was running low. ${ }^{57}$ As expected, Hanoi launched a major offensive against the South on March 30, 1972. Nixon and Kissinger decided to respond forcefully, by mining North Vietnam's Haiphong harbor, thus starving Hanoi of Soviet supplies, and by undertaking a massive bombing of the roads and rail lines from China, which would be the preferred alternative route for supplies. ${ }^{58}$

Beyond direct military action with U.S. and South Vietnamese troops to counter the North Vietnamese offensive, Nixon and Kissinger sought new sources of pressure on Hanoi. Given that both Communist giants provided extensive diplomatic and military support for North Vietnam, Nixon and Kissinger sought to reduce or eliminate it. To do so, they consciously linked the U.S. policy in Vietnam to the developing détente with Moscow and the nascent rapprochement with Beijing.

Seeking Chinese Assistance on Vietnam. Soon after coming into office, President Nixon and Kissinger acted on a historic opportunity to explore positive relations with Beijing, hoping to overcome the mutual hostility of the preceding years. ${ }^{59}$ They capitalized on the deteriorating Sino-Soviet relationship, which had continued to sour since the mid-1960s with the Soviets increasing troop numbers from 12 to 40 divisions along the Sino-Soviet border. ${ }^{60}$ In August 1969, indications appeared that the Soviets were considering bombing China's early-stage nuclear facilities. ${ }^{61}$

A U.S. message to Moscow in early September 1969 warning against attacking China was a key early part of the effort to dispel Mao's original fear that the U.S. would cooperate with the USSR against China. ${ }^{62}$ Yet, Kissinger needed to confirm that, at a minimum, China's close links to North Vietnam would not preclude a U.S.-Chinese rapprochement. As the relationship developed, Kissinger increasingly made clear to his Chinese interlocutors that U.S.-Chinese strategic cooperation was partially linked to China's assistance in reining in its North Vietnamese client-a point that was not lost on the Chinese. During the 
first meeting between Zhou Enlai and Kissinger, Zhou remarked about North Vietnam: "we still feel a deep and full sympathy for them." Kissinger noted afterwards: "Sympathy, of course, was not the same as political or military support; it was a delicate way to convey that China would not become involved militarily or press us diplomatically." 63

Kissinger judged better U.S.-Chinese relations to be intrinsically worthwhile. Yet a U.S. rapprochement with Beijing could also induce the Soviets to moderate their foreign policy behavior, especially their support of North Vietnam, in order to avoid provoking a closer Sino-U.S. collaboration against Moscow. Ideally, a U.S. move toward China would provide enough incentives to the Chinese to be cooperative (e.g., moderate their material support for North Vietnam, help to diplomatically isolate Hanoi), but not so much as to allow them to take the U.S. cooperation for granted. Since the U.S. attitude included both the prospect of improving relations and a possibility of reverting to the status quo, it tended to institutionalize the strategic dependence of the Chinese. ${ }^{64}$

In practice, American diplomacy with China had three distinct effects on efforts to negotiate a settlement to the Vietnam conflict. First, unlike the Korean War, in which Chinese troops became directly involved in battles with American forces, China gave tacit (and true) assurances to Kissinger that its forces would not become similarly involved. Second, to an extent that is still debated, China softened its support for Hanoi and helped to isolate North Vietnam diplomatically. ${ }^{65}$ Third, the threat of a developing U.S.-China axis led the Soviets to moderate their support for Hanoi.

Seeking Soviet Cooperation on Vietnam. Building on the developing rapprochement with China, Kissinger sought to persuade the Soviets to sharply reduce their diplomatic and military support for North Vietnam by threatening Moscow with abandoning détente and risking its potential benefits. ${ }^{66}$ During the Johnson Administration, Kissinger assessed, the Soviets had not cooperated in helping to end the war because they had not borne meaningful costs for their support of North Vietnam. ${ }^{67}$ Kissinger calculated that détente had already built up the Soviet "stake" in its bilateral relationship with the United States (which, Kissinger recognized, Moscow cultivated in part to counterbalance the burgeoning U.S. relationship with China) and that improvement thus far had whetted Moscow's appetite for further progress. 68

But how might this Soviet appetite be useful both with respect to arms control (Strategic Arms Limitation Talks or SALT) and Vietnam? Kissinger saw a further potential source of U.S. leverage in its ability to offer (or block) progress toward resolving the long-simmering dispute between the Soviets and the western Allies over the status of Germany. This dispute had hampered Soviet efforts to expand valuable trade and diplomatic efforts with Europe. ${ }^{69}$

This was the case since, after World War II, the four Allied powers - the United States, Soviet Union, France, and Britain-maintained military control over Germany. As a democratic West German state emerged alongside a pro-communist, Soviet-backed East German state, tensions had mounted between the two with the status of Berlin as its focus. ${ }^{70}$

The three non-Soviet powers retained military control over West Berlin while the Soviets had walled off East Berlin. West Berliners were not recognized as citizens of the Bonn-based Federal Republic of Germany ("West Germany"). ${ }^{71}$ Throughout the 1960s, with Berlin surrounded by East German territory and supported by vulnerable supply lines from the West, the West Germans and Allies refused to settle significant territorial disputes and wartime claims with the Soviets. Without a settlement, the Soviets' ability to trade, especially with West Europeans, was severely restricted.

In 1969, West German Prime Minister Willy Brandt began a concerted effort ("Ostkpolitik") - largely independent of Washington - to break the impasse with the Soviets. Brandt proposed a series of treaties to reduce tensions by opening trade agreements, resolving disputed territorial claims, and clarifying military arrangements. Brandt's initiative was largely motivated by his goal of keeping the dream of a 
unified German state alive (through engendering Soviet flexibility on this issue).57 Brandt's Ostkpolitik would earn him the Nobel Peace Prize, but Washington was deeply concerned that this policy might lead toward a neutral - possibly nationalist-Germany. Now Kissinger realized that it could be time to carefully soften American reservations about Ostpolitik (which the Soviets eagerly sought) in order to gain potential U.S. leverage on arms control and Vietnam.

A tangible opportunity for such leverage flowed from the so-called "Eastern Treaties," which would enable Moscow to relax its tensions with West Germany and, more broadly, in Europe. ${ }^{72}$ Under the Eastern Treaties championed by Brandt-notably, the 1970 Treaty of Moscow between West Germany and the USSR - the signatories would normalize relations and renounce the use of military force. West Germany and the USSR signed the Moscow on August 12, 1970, though Germany still had to ratify it for the treaty to come into force. Given Brandt's somewhat shaky political situation, Moscow sought the U.S. help in pressing Bonn for prompt ratification (which Kissinger linked to a deal on Berlin). ${ }^{73}$ Privately, Kissinger doubted that the U.S. could effectively intervene in West Germany's domestic politics. Publicly, however, he took advantage of Moscow's assumption that the American support was crucial to achieve German ratification.

During a conversation with Soviet Ambassador Anatoly Dobrynin, Kissinger accused Moscow of "complicity" in Hanoi's March 1972 offensive against South Vietnam, and stated explicitly that the Soviet support for North Vietnam now posed grave difficulties for Washington to cooperate with Moscow on the Eastern treaties. ${ }^{74}$ Lest the Soviets fail to get the seriousness of this message, Kissinger communicated the same point to Egon Bahr, Brandt's adviser, with the expectation that Bahr would pass the message to the Soviet Ambassador in Bonn. ${ }^{75}$

Nixon's public revelations about American negotiating flexibility and major concessions in the Paris talks contrasted with North Vietnamese intransigence. At one point, Kissinger told Soviet Ambassador Anatoly Dobrynin that, "the Soviets had put themselves into the position where a miserable little country [North Vietnam] could jeopardize everything that had been negotiated for years."76

Georgy Arbatov, a Soviet expert on American politics, advised five General Secretaries of the Soviet Union. "Kissinger thinks it was China that played the decisive role in getting us to feel the need to preserve our relationship with the U.S.A." Arbatov reflected, "But Berlin actually played a much bigger role, almost a decisive one. Having the East German situation settled was most important to us, and we did not want to jeopardize that." 77

Kissinger used the impending May 1972 Soviet-American presidential summit in Moscow - which would include the signing of the SALT agreement - as another forcing point. During a pre-summit meeting with Soviet leader Leonid Brezhnev in Moscow, he pointedly complained about the continued stalling tactics by the North Vietnamese and ended with a stern warning: "If this process is maintained we will act unilaterally at whatever risk to whatever relationship."78 Kissinger knew, however, that Moscow was unlikely to exert decisive pressure on Hanoi. ${ }^{79}$

At the same time, he explicitly articulated a major American concession to the Soviet leader that mirrored what he had been quietly signaling to Le Duc Tho: the United States would not demand a complete withdrawal of the regular North Vietnamese forces from South Vietnam in return for the North Vietnamese relinquishing their demand to forcibly remove Thieu from power. ${ }^{80}$

On May 9, Nixon announced the U.S. response to North Vietnam's March 1972 offensive against the South: the mining of the Haiphong harbor and the bombing of the transportation links from China. Along with these powerful military actions, he offered to withdraw all troops within four months. ${ }^{81}$ In a tacit but clear concession of immense significance both to North Vietnam and Moscow, the President did not demand that the North Vietnamese regular forces withdraw as a condition for the end of bombing and mining. ${ }^{82}$ Renewed domestic protests greeted Nixon's decision..$^{83}$ 
On the diplomatic front, major progress ensued. The Moscow summit took place, SALT Treaty was signed, and the USSR assumed a more restrained public posture vis-à-vis Hanoi. Privately, the Soviets did not meaningfully object to the American military actions while exerting a degree of pressure on Hanoi to be more forthcoming in negotiations. ${ }^{84}$

Persuading South Vietnamese President Thieu to Agree. Expecting a breakthrough in the negotiations, Kissinger kept in contact with President Nguyen Van Thieu in Saigon. ${ }^{85}$ He did not, however, reveal the full extent of American concessions to Hanoi. Al Haig, Kissinger's military assistant, briefed Thieu in Saigon on August 17 on the emerging agreement and gave him a letter of reassurance from Nixon, who pledged continued support for Saigon after the war. ${ }^{86}$ But it was not clear whether the South Vietnamese leader would eventually accept the agreement.

On October 8, 1972, Le Duc Tho dropped North Vietnam's longstanding demand for the United States to force regime change in Saigon as a condition for the deal. The provisional agreement included a ceasefire, the withdrawal of American forces, cessation of North Vietnamese infiltration of South Vietnam from Laos and Cambodia, and the release of the American prisoners of war. ${ }^{87}$ Kissinger and his associates were privately jubilant at what finally appeared as the breakthrough they had sought. ${ }^{88}$

Almost immediately, persuading President Thieu-using both threats and assurances - to accept the negotiated outcome became Kissinger's top priority. The threats-delivered orally and in writingcentered on the possibility of the complete cut-off of American aid in case Saigon refused to go along with the negotiated framework. ${ }^{89}$ Along with the threats, Kissinger frequently communicated Nixon's assurances, which revolved around the President's stated determination to stand by its ally in Saigon in responding to the massive violations of the agreement by the North Vietnamese. ${ }^{90}$

Nixon embodied the credibility of these promises and threats. Reelected in a massive 1972 landslide against the anti-war candidate George McGovern, he enjoyed a significant popular mandate. ${ }^{11}$ "Our thinking," Kissinger remembered, "was that the agreement could be preserved unless the North Vietnamese launched another all-out offensive, in which case we believed that a combination of American air power and existing South Vietnamese ground forces could repeat the experience of ' 72 [the successful American and South Vietnamese military response to the March 30, 1972 North Vietnamese offensive]."92

From early October until mid-November 1972, Thieu artfully postponed his acceptance of the agreement, requesting a number of changes. ${ }^{93}$ It was becoming increasingly clear to Kissinger that Saigon was interested not in a negotiated compromise, but in a total U.S. victory over Hanoi..$^{94}$

Nonetheless, Kissinger negotiated with Le Duc Tho from November 20 to 25 and from December 4 to 13 in order to achieve the changes Thieu sought. ${ }^{95}$ Le Duc Tho dragged out the negotiations without any substantive results. ${ }^{96}$ To force Hanoi's hand and help persuade Thieu of American resolve to settle the war, Kissinger and Nixon decided on a short, but powerful military response: on December 17, the United States again mined the Haiphong Harbor, and bombed North Vietnam from December 18 to 29.97 On the same day that this so-called "Christmas bombing" began, Washington proposed renewed negotiations. Kissinger met Tho on January 8 who, on January 9, agreed to sign the agreement, which was largely unchanged from the pre-Christmas version. ${ }^{98}$ From January 14 to 21 , there were final efforts to persuade a deeply reluctant Thieu to sign the accord, which he did and that came into effect on January 27, 1973.99

The Aftermath. Hanoi proceeded to "immediately and grossly" violate the Paris Peace Accords, continuing the infiltration and attacks against South Vietnam. ${ }^{100}$ Kissinger reflected years later: "had Nixon stayed in office, we would surely have attacked their [North Vietnamese] supply lines [through Cambodia and Laos]." 101 The United States responded with focused bombing campaigns - on March 22-23 and April 16-17, 1973 - but it was clear to Kissinger that President Nixon was too preoccupied by Watergate to pursue this as forcefully as he had previously done. 
Amid Watergate investigations and with the American public largely sick of the seemingly endless involvement in Vietnam, Congress voted in June 1973 to prohibit further U.S. military involvement in Indochina after August 15.102 The "stick of bombing was lost by our own domestic incapacity. ...the 'window' we had in those few months of early 1973 [before the June cut off] was closed by Watergate's enfeeblements." 103

On September 22, 1973, Kissinger was sworn in as the $56^{\text {th }}$ Secretary of State, and on October 16, 1973, he and Le Duc Tho were awarded the Nobel Peace Prize for the negotiation of the Paris Peace Accords. Le Duc Tho refused to accept the prize. Kissinger donated the monetary proceeds of the award to a scholarship fund for the children of American soldiers killed or missing in Vietnam, and later sought, unsuccessfully, to return the prize.

Amid Watergate, Nixon resigned in August 1974-the first U.S. President to do so. North Vietnam conquered South Vietnam on April, 30 1975. After the last U.S. personnel flew out of Saigon, Kissinger said that "only a feeling of emptiness remained."104 According to Alistair Horne, one of Kissinger's biographers, the failure in Vietnam is "the outstanding disappointment of his [Kissinger's] life - a source of never-ending regret." 105 "It was, to me," Kissinger reflected, "the saddest point in my governmental experience." 106

\section{Bibliography}

\section{Books and Journals}

Brinkley, Douglas. Tour of Duty: John Kerry and the Vietnam War. New York: William Morrow, 2004.

Dobrynin, Anatoly. In Confidence: Moscow's Ambassador to America's Six Cold War Presidents (1962 - 1986). New York: Random House, 1995.

Ferguson, Niall. Kissinger. New York: Penguin Press, 2015.

Fry, Joseph A. Unpopular Messengers: Student Opposition to the Vietnam War. In Anderson, David L. and Ernst, John, eds. The War That Never Ends: New Perspectives on the Vietnam War. Lexington, KY: The University Press of Kentucky, 2007.

Hersh, Seymour M. The Price of Power: Kissinger in the Nixon White House. New York: Summit Books, 1983.

Hirschman, Charles, Samuel Preston, and Loi, Vu Manh. Vietnamese Casualties During the American War: A New Estimate. Population and Development Review: Vol. 21, No. 4, 1995: 783-812.

Hitchens, Christopher. The Trial of Henry Kissinger. London: Verso, 2001.

Horne, Alastair. Kissinger: 1973, The Crucial Year. New York: Simon and Schuster, 2009.

Isaacson, Walter. Kissinger: A Biography. New York: Simon \& Schuster, 1992.

Kalb, Marvin and Kalb, Bernard. Kissinger. New York: Little Brown \& Company, 1974.

Keithly, David M. Breakthrough in the Ostpolitik: The 1971 Quadripartite Agreement. Boulder and London: Westview Special Studies in International Relations, 1986.

Kissinger, Henry A. Diplomacy. New York: Simon and Schuster, 1994.

Kissinger, Henry A. Interview with American Secretaries of State Project (SOSP). Harvard University, 6 Nov 2014.

Copyright 2016 (C) James K. Sebenius 


\section{Henry A. Kissinger as Negotiator}

Kissinger, Henry A. On China. New York: Penguin, 2012.

Kissinger, Henry A. The Viet Nam Negotiations. Foreign Affairs: January 1, 1969.

Kissinger, Henry A. White House Years. New York: Simon and Schuster, 1979.

Kissinger, Henry A. Years of Renewal. New York: Simon and Schuster, 1999.

Kissinger, Henry A. Years of Upheaval. New York: Little Brown and Company, 1982.

Lanning, Michael L. and Cragg, Dan. Inside the VC and the NVA: The Real Story of North Vietnam's Armed Forces. New York: Fawcett Columbine, 1992.

Lax, David A. and Sebenius, James K. From Single Deals to Negotiation Campaigns. Harvard Business School Working Paper 12-046, 2011.

Moise, Edwin E. Tonkin Gulf and the Escalation of the Vietnam War. Chapel Hill, NC: University of North Carolina Press, 1996.

Mott, William H. Soviet Military Assistance: An Empirical Perspective. Westport, CT: Greenwood Press, 2001.

Sarin, Oleg and Dvoretsky, Lev. Alien Wars: The Soviet Union's Aggressions Against the World, 1919 to 1989. Novato, CA: Presidio, 1996.

Sebenius, James K. Beyond the Deal: Wage a 'Negotiation Campaign'. Negotiation: Vol. 13, No. 11, 2010.

Shawcross, William. Sideshow: Kissinger, Nixon and the Destruction of Cambodia. New York: Pocket Books, 1979.

Steel, Ronald. Walter Lippmann and the American Century. Boston, MA: Little, Brown and Company, 1980.

Szulc, Tad. How Kissinger Did It: Behind the Vietnam Cease-Fire Agreement. Foreign Policy: Summer, 1974.

Tang, Truong N. Vietcong Memoir. New York: Harcourt Brace Jovanovich, Publishers, 1985.

Ulam, Adam B. Expansion and Coexistence: The History of Soviet Foreign Policy, 1917-67. New York: Praeger, 1968.

Van Alstyne, William W. Congress, the President, and the Power to Declare War: A Requiem for Vietnam. University of Pennsylvania Law Review: Vol. 121, No. 1, 1972.

Womack, Brantly. China and Vietnam: The Politics of Asymmetry. New York: Cambridge University Press, 2006.

\section{Websites}

Butterfield, Fox. "Nguyen Van Thieu Is Dead at 76; Last President of South Vietnam," New York Times, October 1, 2001. http:/ / www.nytimes.com/2001/10/01/us/nguyen-van-thieu-is-dead-at-76-last-president-of-southvietnam.html?sec=\&spon=\&pagewanted=3, accessed November 2016.

“Germany, a Country Study," Federal Research Division, p. 107. Library of Congress, 1996. http://usa.usembassy.de/etexts/ga5710903.htm, accessed November 2016.

Gitlin, Todd. "Kissinger Was a Courtier to Atrocity," New York Times "Room for Debate," February $13,2016$. http://www.nytimes.com/roomfordebate/2016/02/13/henry-kissinger-sage-or-pariah/ kissinger-was-a-courtier-toatrocity, accessed November 2016.

Grandin, Greg. “Henry Kissinger, Hillary Clinton's Tutor in War and Peace," The Nation, February 5 , 2016. https://www.thenation.com/article/henry-kissinger-hillary-clintons-tutor-in-war-and-peace/, accessed November 2016.

Grandin, Greg. "Henry Kissinger's 'mad and illegal' bombing: What you need to know about his real history-and why the Sanders/Clinton exchange matters," Salon, February 12, 2016. http://www.salon.com/2016/02/12/henry_kissingers_mad_and_illegal_bombing_what_you_need_to_know_about_his _real_history_and_why_the_sandersclinton_exchange_matters/, accessed November 2016.

Grandin, Greg. “How Henry Kissinger Helped Create Our 'Proliferated' World," TomDispatch.com, September $27,2015$. http://www.tomdispatch.com/post/176049/tomgram\%3A_greg_grandin,_henry_of_arabia/, accessed November 2016.

Copyright 2016 @ James K. Sebenius 


\section{Henry A. Kissinger as Negotiator}

Grandin, Greg. "The Obama Administration Just Granted Henry Kissinger a Distinguished Public Service Award," The Nation, May 10, 2016. https://www.thenation.com/article/the-obama-administration-just-granted-henry-kissinger-a-distinguishedpublic-service-award/, accessed November 2016.

Horne, Alistair. "The Case for Henry Kissinger," The Independent, August 18, 2009.

http://www.independent.co.uk/news/world/americas/the-case-for-henry-kissinger-1773365.html, accessed November 2016.

“Oral History Interview with Winston Lord," April 28, 1998, Association for Diplomatic Studies and Training, Foreign Affairs Oral History Project. http:/ / www.adst.org/OH\%20TOCs/Lord,\%20Winston.pdf, accessed November 2016.

"The Trials of Henry Kissinger," 2002. https:/ / www.youtube.com/watch?v=PmOb6DRrLWg\&t=27m42s

[27.42 - 28.15], accessed November 2016.

“Vietnam War and the Presidency: Inside the White House II," March 10-11, 2006. https:/ / www.youtube.com/watch?v=C_YCdFIOB3E [6.36 - 11.18] and [10.55 - 11.18], accessed November 2016.

“The Vietnam War Summit,” April 26, 2016. https:// www.youtube.com/watch?v=1CsFYSC86bU\&list=PLE4ezrXJCEOQo_8kvdscLVJ8dysb8tQVC\&index=5 [1.10.39 -1.10.53] , accessed November 2016.

“The Week that Changed the World," March 7, 2012. https://www.youtube.com/v/fmwJAWNEG_U?start=6549\&end=6621, accessed November 2016. 


\section{Endnotes}

${ }^{1}$ Between 791,000 and 1,141,000 Vietnamese died in the war between 1965 and 1975. See, Charles Hirschman, Samuel Preston, and Vu Manh Loi, "Vietnamese Casualties During the American War: A New Estimate," Population and Development Review, Vol. 21, No. 4, December 1995, p. 807.

On divisions in American society, see, White House Years, p. 1473; Years of Upheaval, p. 83. All the forthcoming abbreviated references, are to the following works by Henry Kissinger (listed in chronological order by year of publication): White House Years (New York: Simon and Schuster, 1979); Years of Upheaval (New York: Little Brown and Company, 1982); Diplomacy (New York: Simon and Schuster, 1994); Years of Renewal (New York: Simon and Schuster, 1999); On China (New York: Penguin, 2012).

2 In May 1959, the leadership of North Vietnam's Communist party formally decided to overthrow the government of South Vietnam through Maoist insurgent warfare to be conducted by the 5,500-man-strong Vietcong guerilla force, which would operate within South Vietnam. See, William H. Mott, IV, Soviet Military Assistance: An Empirical Perspective (Westport, CT: Greenwood Press, 2001), pp. 244-245. Also see, Diplomacy, pp. 639-640. In doing so, Hanoi decided to abandon the outcome of the 1954 Geneva Accords which envisioned an electoral process to decide the political future of South Vietnam. Interview with John Negroponte at Yale University, November 30, 2015. (But Hanoi only committed regular North Vietnamese forces to fight in the South in September 1964. See, Niall Ferguson, Kissinger, Volume 1: The Idealist [New York: Penguin, 2015], p. 611.) The National Liberation Front for the Liberation of the South (NLF), a political representative of the insurgency, was founded in early 1961 and would represent the guerillas at the plenary Paris peace negotiations from 1968 to 1973. See, William H. Mott, IV, Soviet Military Assistance: An Empirical Perspective (Westport, CT: Greenwood Press, 2001), p. 241. In addition, the Provisional Revolutionary Government of South Vietnam (PRG) was established as the Vietcong's government-in-waiting in 1969. See, Truong Nhu Tang, Vietcong Memoir (New York, Harcourt Brace Jovanovich, Publishers, 1985), p. xi. The PRG was the political arm of the Vietcong, and, essentially, a new name for the NLF, which represented the Vietcong at the public peace negotiations in Paris.

${ }^{3}$ Interview with John Negroponte at Yale University, November 30, 2015.

${ }^{4}$ White House Years, pp. 1106-1107.

${ }^{5}$ While the first secret negotiation took place in August 1969 between Kissinger and Xuan Thuy (a North Vietnamese Foreign Ministry official), it soon became clear to Kissinger that Le Duc Tho - not Thuy - was the real negotiator. The Kissinger-Tho meetings produced all of the substantive progress at the secret talks.

${ }^{6} \mathrm{~A}$ "negotiation campaign" consists of several "individual but linked negotiations involving an array of parties over time and across borders." See, James K. Sebenius, "Beyond the Deal: Wage a 'Negotiation Campaign'," Negotiation 13, no. 11 (November 2010), p. 2. See also, David A. Lax and James K. Sebenius, "From Single Deals to Negotiation Campaigns," Harvard Business School Working Paper 12-046, December 17, 2011.

7 There was a de facto commonality of interest between Hanoi and the anti-war protesters. Consider, for instance, Le Duc Tho's comment to Kissinger in September 1971: "I really don't know why I am negotiating anything with you. I have just spent several hours with Senator [George] McGovern and your opposition will force you to give me what I want..." Vernon Walters, who accompanied Kissinger, recalled about Le Duc Tho: "The note of triumph in his voice was grinding." See, Alastair Horne, Kissinger: 1973, The Crucial Year (New York: Simon and Schuster, 2009), p. 51.

8 "[From China's perspective] As long as [North Vietnamese leader] Ho [Chi Minh] continued fighting, anti-communist forces would be distracted from tightening the noose around China itself." See, Brantly Womack, China and Vietnam: The Politics of Asymmetry (New York: Cambridge University Press, 2006), p. 166.

${ }^{9}$ It was at this conference that Secretary of State John Foster Dulles refused to shake hands with Zhou Enlai-an affront that Zhou recalled in July 1971 when Kissinger arrived in Beijing for the first time. See Diplomacy, p. 719. A divided-and thus dependent-Vietnam was in China's interest. See, Diplomacy, p. 635. For example, Historian Adam Ulam argues: "For China...the [1954 Geneva] settlement represented an unqualified diplomatic success. Continued fighting would have meant the probability of American bases and soldiers on China's frontiers. Now there would be a Communist buffer state, and the very incompleteness of Ho Chi Minh's success would make him more dependent on China than would otherwise be the case." See, Adam B. Ulam, Expansion and Coexistence: The History of Soviet Foreign Policy, 1917-67 (New York: Praeger, 1968), p. 553.

Copyright 2016 ㄷ James K. Sebenius 
${ }^{10}$ Diplomacy, p. 639.

11 Diplomacy, p. 653.

12 Brantly Womack, China and Vietnam: The Politics of Asymmetry (New York: Cambridge University Press, 2006), p. 172. Kissinger pointedly draws a distinction between Nixon's and Kennedy's approach to South Vietnam: "Nixon persisted in his course [in the Vietnam War] and I in my defense of it, not because we wanted to continue the war but because we could not agree that we should overthrow a friendly government (put into office by a coup organized by our predecessors) and mock the sacrifice of millions who had relied on us, as the price for getting out." See, White House Years, p. 1013. Elsewhere, he expounded on his opposition to regime change in Saigon: "The chief object of any guerilla war is to demoralize the existing government. If we undermine the Diem regime, we are really doing the Viet Cong's work for them." Quoted in Niall Ferguson, Kissinger, Volume 1: The Idealist (New York: Penguin, 2015), p. 592.

${ }^{13}$ Fox Butterfield, “Nguyen Van Thieu Is Dead at 76; Last President of South Vietnam," New York Times, October 1, 2001, available at http:/ / www.nytimes.com/2001/10/01/us/nguyen-van-thieu-is-dead-at-76-last-president-of-southvietnam.html?sec $=\&$ spon $=\&$ pagewanted $=3$.

14 The Gulf of Tonkin resolution is controversial and a number of scholars argue that the Johnson Administration used the Gulf of Tonkin incident as a pretext to unleash the war in Indochina. See, for example, Edwin E. Moise, Tonkin Gulfand the Escalation of the Vietnam War (Chapel Hill, NC: University of North Carolina Press, 1996). Kissinger acknowledges that by 1965, he was part of the "silent majority" in supporting the deployment of U.S. troops to Vietnam. See, White House Years, p. 231. For a review of the issues of fact, law, and policy relating to the Gulf of Tonkin Resolution and its subsequent application to the President's power to make war in Vietnam, see William W. Van Alstyne, "Congress, the President, and the Power to Declare War: A Requiem for Vietnam," University of Pennsylvania Law Review (1972) vol. 121, no. 1, pp. 1-28.

15 Union of Soviet Socialist Republics was the formal name of the Soviet Union.

16 Isolated incidents notwithstanding, China unenthusiastically agreed to allow the Soviet aid to be transported by rail through Chinese territory. See, Brantly Womack, China and Vietnam: The Politics of Asymmetry (New York: Cambridge University Press, 2006), p. 177. For example, Adam Ulam references an instance in 1965 where Beijing declined Moscow's request to allow 4,000 Soviet troops to pass through Chinese territory, and to establish air bases in China in order to transport war supplies for the North Vietnamese. See, Adam B. Ulam, Expansion and Coexistence: The History of Soviet Foreign Policy, 191767 (New York: Praeger, 1968), p. 705. With the intensification of the Sino-Soviet split, after 1968, Soviet planes had to fly through Afghanistan, Pakistan, India, and Burma. See, Oleg Sarin and Lev Dvoretsky, Alien Wars: The Soviet Union's Aggressions Against the World, 1919 to 1989 (Novato, CA: Presidio, 1996), p. 96.

${ }^{17}$ Michael Lee Lanning and Dan Cragg, Inside the VC and the NVA: The Real Story of North Vietnam's Armed Forces (New York: Fawcett Columbine, 1992), p. 119.

18 Brantly Womack, China and Vietnam: The Politics of Asymmetry (New York: Cambridge University Press, 2006), p. 176.

${ }^{19}$ Michael Lee Lanning and Dan Cragg, Inside the VC and the NVA: The Real Story of North Vietnam's Armed Forces (New York: Fawcett Columbine, 1992), p. 119. Adam B. Ulam, Expansion and Coexistence: The History of Soviet Foreign Policy, 1917-67 (New York: Praeger, 1968), p. 699. Also see, William H. Mott, IV, Soviet Military Assistance: An Empirical Perspective (Westport, CT: Greenwood Press, 2001), p. 239.

20 Oleg Sarin and Lev Dvoretsky, Alien Wars: The Soviet Union's Aggressions Against the World, 1919 to 1989 (Novato, CA: Presidio, 1996), p. 91.

${ }^{21}$ William H. Mott, IV, Soviet Military Assistance: An Empirical Perspective (Westport, CT: Greenwood Press, 2001), p. 239.

22 Adam B. Ulam, Expansion and Coexistence: The History of Soviet Foreign Policy, 1917-67 (New York: Praeger, 1968$),$ p. 741.

${ }^{23}$ Brantly Womack, China and Vietnam: The Politics of Asymmetry (New York: Cambridge University Press, 2006), p. 177. William H. Mott, IV, Soviet Military Assistance: An Empirical Perspective (Westport, CT: Greenwood Press, 2001), p. 240.

24 Brantly Womack, China and Vietnam: The Politics of Asymmetry (New York: Cambridge University Press, 2006), p. 173. William H. Mott, IV, Soviet Military Assistance: An Empirical Perspective (Westport, CT: Greenwood Press, 2001), p. 241. Also see, Ronald Steel, Walter Lippmann and the American Century (Boston, MA: Little, Brown and Company, 1980), p. 557. 
25 “By May 1965, 47,000 American combat troops were already in Vietnam.” See, Niall Ferguson, Kissinger, Volume 1: The Idealist (New York: Penguin, 2015), p. 614.

${ }^{26}$ Joseph A. Fry, “Unpopular Messengers: Student Opposition to the Vietnam War.” In David L. Anderson and John Ernst, eds., The War That Never Ends: New Perspectives on the Vietnam War (Lexington, KY: The University Press of Kentucky, 2007), p. 227.

27 White House Years, p. 481. Also, Years of Upheaval, p. 83.

${ }^{28}$ White House Years, p. 237.

${ }^{29}$ White House Years, pp. 258-9. See also Years of Renewal, p. 468. In its December 31, 1968 message Hanoi called for the "replacement of ... the 'Thieu-Ky-Huong' clique, its pet phrase for the leadership in Saigon with which Hanoi was supposed to be negotiating." See, White House Years, p. 259. Nguyen Van Thieu, Nguyen Cao Ky and Tran Van Huong were, respectively, President, Vice President and Prime Minister of South Vietnam. See, White House Years, p. 444. Indeed, Kissinger recalled, "our refusal to overthrow an allied government [in Saigon] remained the single and crucial issue that deadlocked all negotiation until October 8, 1972, when Hanoi withdrew the demand." See, White House Years, p. 282. Kissinger explained: "Our definition of honor was not extravagant: We would withdraw, but we would not overthrow an allied government. We were prepared to accept the outcome of a truly free political process in South Vietnam even if it meant the replacement of the personalities and institutions that we favored. What we were not willing to do was to accept the unconditional surrender Hanoi was in effect demanding, to mock our people's sacrifices by collaborating in the imposition of Communist rule, betraying those who had believed the assurances of our predecessors and thereby putting at risk global confidence in the United States.

But a free political process was precisely what Hanoi was determined to prevent. Its dour and fanatical leaders had not fought and suffered for all their adult lives to entrust the outcome to an electoral procedure that they had never practiced in their own country." See, Years of Upheaval, p. 83, emphasis added. Kissinger concludes: "The [Vietnam] war concerned not the support of a particular government [in South Vietnam] but the legitimacy of any non-Communist structure." See, Years of Upheaval, p. 85, emphasis in original.

30 White House Years, p. 240. Also, “Vietnam War and the Presidency: Inside the White House II," March 10-11, 2006, https://www.youtube.com/watch?v=C_YCdFIOB3E [6.36 - 11.18].

${ }^{31}$ Douglas Brinkley, Tour of Duty: John Kerry and the Vietnam War (New York: William Morrow, 2004), p. 323. Kissinger argues that the bombing was performed within 5-6 miles of the border. See, White House Years, p. 254; Years of Renewal, p. 497. Another source suggests it was 10 miles. See, Marvin Kalb and Bernard Kalb, Kissinger (New York: Little Brown \& Company, 1974), p. 131.

32 White House Years, p. 240.

33 Critics argue that the operation was secret and that Kissinger "approved a plan to conceal the Cambodian bombing missions from military records. See "The Trials of Henry Kissinger," 2002, https://www.youtube.com/watch?v=PmOb6DRrLWg\&t=27m42s [27.42 - 28.15]. "From the very start," writes Walter Isaacson, "the plans contained provisions for handling press inquiries: 'Spokesman will confirm that B-52s did strike on routine missions adjacent to the Cambodian border but state that he has no details and will look into it."' See, Walter Isaacson, Kissinger: A Biography (New York: Simon \& Schuster, 1992), p. 179. Responding to Kissinger's argument that Congress was informed about the bombing, Isaacson writes: "The air force secretary and other top officials were not informed of the raids at all, and even the State Department was kept in the dark. A few selected congressmen were informed of the initial raid, but there was no effort to consult with Congress formally or to be frank about the extent of the operations - something that Kissinger later admitted he regretted. Even in 1971, a year after the secret bombing program had ended and well after Cambodia had been plunged into an open war, the Senate Armed Services Committee in a closed hearing on bombing targets was told by military officials that there 'was no B-52 bombing in Cambodia of any kind during the entire year of 1969.'” See, Walter Isaacson, Kissinger: A Biography (New York: Simon \& Schuster, 1992), pp. 176177. By contrast, Kissinger said "Key members of Congress were briefed, including the chairmen of the Armed Services and Appropriations Committees, the Speaker - all of them Democrats - and other congressional leaders. I recall no objections nor any urging to widen the circle of those privy to the information." See, Years of Renewal, p. 497. Alexander Haig emphatically re-affirms that Congress was "fully informed" about the Cambodia operation. See, "Vietnam War and the Presidency: Inside the White House II," March 10-11, 2006,

https://www.youtube.com/watch?v=C_YCdFIOB3E\&t=10m55s [10.55 - 11.18]. Kalb and Kalb confirm that the bombings received press coverage. See, Marvin Kalb and Bernard Kalb, Kissinger (New York: Little Brown \& Company, 1974), p. 133. Critics also posit that this "carpet bombing" produced significant civilian casualties, prompted an expansion of North Vietnamese forces within Cambodia, and ultimately led to the horrors of the Khmer Rouge. See "The Vietnam War Summit," April 26, 2016, 
https://www.youtube.com/watch?v=1CsFYSC86bU\&list=PLE4ezrXJCEOQo_8kvdscLVJ8dysb8tQVC\&index=5 [1.10.39 $-1.10 .53]$.

34 White House Years, p. 291.

${ }^{35}$ Diplomacy, p. 689.

${ }^{36}$ White House Years, p. 271, 283, 475, 481, 1101, 1329.

${ }^{37}$ White House Years, p. 436.

${ }^{38}$ White House Years, p. 275. Kissinger further reflected: "No negotiator, least of all the hard-boiled revolutionaries from Hanoi, will settle so long as he knows that his opposite number will be prevented from sticking to a position by constantly escalating domestic pressures." See, Years of Upheaval, p. 86.

${ }^{39}$ White House Years, p. 1101.

40 White House Years, pp. 440-448, esp., p. 445. Seeking to induce Hanoi to compromise, Kissinger told Le Duc Tho that the U.S. did not require the North Vietnamese to withdraw its troops publicly-i.e., the U.S. would not make an effort to humiliate Hanoi. See, White House Years, p. 443. Yet, Hanoi repeatedly denied having troops within South Vietnam. See, Tad Szulc, "How Kissinger Did It: Behind the Vietnam Cease-Fire Agreement," Foreign Policy, Summer, 1974, p. 25.

${ }^{41}$ White House Years, p. 976, 1018.

42 In fact, Le Duc Tho made repeatedly clear that "even if we [U.S.] withdrew, Hanoi would stop fighting only if there were a political settlement" that included the overthrow of the Thieu government. See, White House Years, p. 444. At one point, Le Duc Tho advised Kissinger that Thieu did not have to be removed publicly; this could be done secretly--for example, through assassination. This suggestion elicited such a strong response from Kissinger that even the usually imperturbable Tho was "temporarily flustered. He obviously had trouble understanding what I was getting so excited about." See, White House Years, pp. 1030-1031.

43 The Kissinger-Le Duc Tho secret negotiations would only be made public in January 1972.

44 White House Years, pp. 980-981.

45 Years of Upheaval, p. 86. When leaving office, President Dwight Eisenhower warned President John Kennedy that the situation in Laos was "the most important problem facing the U.S." Quoted in Niall Ferguson, Kissinger, Volume 1: The Idealist (New York: Penguin, 2015), p. 585.

46 Seymour M. Hersh, The Price of Power: Kissinger in the Nixon White House (New York: Summit Books, 1983), pp. 121-122. See also, Greg Grandin, "Henry Kissinger, Hillary Clinton's Tutor in War and Peace," The Nation, February 5, 2016, https://www.thenation.com/article/henry-kissinger-hillary-clintons-tutor-in-war-and-peace/. According to Grandin, Kissinger is responsible for some 3-4 millions of deaths through his international policies. Also see, Greg Grandin, "How Henry Kissinger Helped Create Our 'Proliferated' World," TomDispatch.com, September 27, 2015, http://www.tomdispatch.com/post/176049/tomgram\%3A_greg_grandin,_henry_of_arabia/; Greg Grandin, “The Obama Administration Just Granted Henry Kissinger a Distinguished Public Service Award," The Nation, May 10, 2016, https://www.thenation.com/article/the-obama-administration-just-granted-henry-kissinger-a-distinguished-publicservice-award/; Seymour M. Hersh, The Price of Power: Kissinger in the Nixon White House (New York: Summit Books, 1983), p. 177; Christopher Hitchens, The Trial of Henry Kissinger (London: Verso, 2001), pp. 38-39.

47 Seymour M. Hersh, The Price of Power: Kissinger in the Nixon White House (New York: Summit Books, 1983), p. 186. Also see, Todd Gitlin, "Kissinger Was a Courtier to Atrocity," New York Times "Room for Debate," February 13, 2016, http://www.nytimes.com/roomfordebate/2016/02/13/henry-kissinger-sage-or-pariah/ kissinger-was-a-courtier-toatrocity. See William Shawcross, Sideshow: Kissinger, Nixon and the Destruction of Cambodia (New York: Pocket Books, 1979), p. 28, 93. Walter Isaacson has a more balanced view: "Although the North Vietnamese had violated Cambodia's neutrality, their camps had not yet disrupted the lives of the Cambodian peasants and fishermen. But that delicate balance began to falter when the American bombing campaign caused the communist camps to disperse over a larger area. The bombing may not have been the main cause of Cambodia's plunge toward chaos a year later, but it did not make Sihanouk's balancing act any easier." See, Walter Isaacson, Kissinger: A Biography (New York: Simon \& Schuster, 1992), p. 177. In a much harsher assessment, Greg Grandin says: “Kissinger didn't create the Khmer Rouge, but his mad and illegal bombing of Cambodia created the conditions where the most genocidal, militant faction of a broad and diverse insurgency could seize control of 
first the insurgency and then the state." See, Greg Grandin, “Henry Kissinger's 'mad and illegal' bombing: What you need to know about his real history-and why the Sanders/Clinton exchange matters," Salon, February 12, 2016 at http://www.salon.com/2016/02/12/henry_kissingers_mad_and_illegal_bombing_what_you_need_to_know_about_his _real_history_and_why_the_sandersclinton_exchange_matters/.

48 William Shawcross, Sideshow: Kissinger, Nixon and the destruction of Cambodia (New York: Simon and Schuster, 1979$),$ p. 172.

${ }^{49}$ Marvin Kalb and Bernard Kalb, Kissinger (Boston: Little, Brown, 1974), p. 172; also, p. 158. Also see, Niall Ferguson, Kissinger, (New York: Penguin Press, 2015), pp. 36-37; White House Years, p. 486; Years of Upheaval, p. 35.

${ }^{50}$ White House Years, p. 262; also p. 311 ("Hanoi's perception of its possibilities").

51 "When the new [Cambodian] government insisted on the withdrawal of all North Vietnamese troops from Cambodian territory, Hanoi reacted by increasing its blatant and menacing violations of Cambodian neutrality. Its forces left the sanctuaries, pushed deep into Cambodia, and threatened to take over the country." See, Years of Renewal, p. 498.

52 White House Years, p. 1017. This concession was not made public.

${ }^{53}$ White House Years, p. 1035.

54 White House Years, p. 1099. Kissinger notes that the Cambodia and Laos operations in 1970 and 1971, respectively, aimed to disrupt the timetable of this offensive.

55 White House Years, pp. 1043-1044. This was, Kissinger noted, an improvement by one month on the last secret offer Kissinger had made to Le Duc Tho.

56 White House Years, pp. 1043-1044.

57 White House Years, p. 1045.

58 White House Years, p. 1178. "A blockade [by intercepting ships, as opposed to mines], in contrast, would produce daily confrontations with the Soviets. Every time a ship was stopped we would see a repetition of the drama of the Cuban missile crisis; our challenge and the Soviet reaction to it would have to be acted out over and over again, probably on television. The danger of some slip or of a pretext for serious incident would be too great." See, White House Years, p. 1179.

Kissinger originally proposed this two-fold plan of attack in a memorandum dated September 11, 1969. At the time, he reflected that he sought to "make the most sweeping and generous proposal of which we were capable, short of overthrowing an allied government but ensuring a free political contest. If it were refused, we would halt troop withdrawals and quarantine North Vietnam by mining its ports and perhaps bombing its rail links to China. The goal would be a rapid negotiated compromise." See, White House Years, p. 284. Kissinger's logic is worth considering in full: "I have always believed that the optimum moment for negotiations is when things appear to be going well. To yield to pressures is to invite them; to acquire the reputation for short staying power is to give the other side a powerful incentive for protracting negotiations. When a concession is made voluntarily it provides the greatest incentive for reciprocity. It also provides the best guarantee for staying power. In the negotiations that I conducted I always tried to determine the most reasonable outcome and then get there rapidly in one or two moves. This was derided as a strategy of 'preemptive concession' by those who like to make their moves in driblets and at the last moment. But I consider that strategy useful primarily for placating bureaucracies and salving consciences. It impresses novices as a demonstration of toughness. Usually it proves to be selfdefeating; shaving the salami encourages the other side to hold on to see what the next concession is likely to be, never sure that one has really reached the rock-bottom position. Thus, in the many negotiations I undertook - with the Vietnamese and others - I favored big steps taken when they were least expected, when there was a minimum of pressure, and creating the presumption that we would stick to that position." See, White House Years, pp. 436-437, emphasis added.

${ }^{59}$ Hence Kissinger writes about the "ideological truce" and "ideological armistice" with China. See, On China, p. 270, 284. After all, he wrote in 1966: "Tactical intransigence and ideological vitality should not be confused with structural rigidity." Quoted in Niall Ferguson, Kissinger, Volume 1: The Idealist (New York: Penguin, 2015), p. 726. Kissinger "began to discern that, despite its obviously revolutionary character, the People's Republic of China could also be brought into the pale of the balance of power." See, Niall Ferguson, Kissinger, Volume 1: The Idealist (New York: Penguin, 2015), p. 704.

${ }^{60}$ White House Years, p. 167.

${ }^{61}$ China exploded its first nuclear bomb in 1964. 
62 On China, p. 219.

63 On China, p. 250. Kissinger dissected one Soviet statement in a similarly fastidious fashion: "the Soviet 'people' (that is, not the government [Kissinger commented]) 'associates itself' with the struggle [by Hanoi versus the U.S.]. The Soviet 'people' would continue to give the Vietnamese people 'the necessary support' (not 'increased' support, as Hanoi asked [Kissinger commented]). The statement reeked of procrastination and hesitation." See, White House Years, p. 1194, emphasis in the original.

64 See, Diplomacy, p. 746.

65 Kissinger argues that linkage played an important role in restraining Beijing's reactions to the American actions against North Vietnam: "Peking...demonstrated that it had its priorities straight. In a conversation with me in New York on May 16 [1972], UN Ambassador Huang Hua repeated the official line that China stood behind its friends. But he did not demur when I pointed out that we had warned Peking at least half a dozen times of our determination to react strongly if Hanoi sought to impose a military solution. Nor did our actions in Vietnam prevent Huang Hua from encouraging a visit by me to Peking in June. We had not only achieved a free hand in Vietnam; we would be able to continue at the same time the construction of the larger design of our foreign policy." See, White House Years, p. 1197, emphasis added. It was "certainly true," Kissinger recently clarified, that China did not assist the U.S. in the actual negotiations with the North Vietnamese, but Beijing's contribution was to "isolate Hanoi": "China played a role in the atmosphere that was created - not in pressing them [Hanoi] on specific points." See, "The Week that Changed the World," March 7, 2012, https://www.youtube.com/v/fmwJAWNEG_U?start=6549\&end=6621. Winston Lord, Kissinger's close associate on China, later clarified: "I don't think the China equation had a major impact on Hanoi. However, this was certainly one of the reasons that we opened up to China and tried to improve relations with Russia, although this was not the main reason." See, "Oral History Interview with Winston Lord," April 28, 1998, Association for Diplomatic Studies and Training, Foreign Affairs Oral History Project, http://www.adst.org/OH\%20TOCs/Lord,\%20Winston.pdf.

66 See, White House Years, p. 1116, and also p. 1113. Kissinger elaborated on this logic of isolating an adversary by comparing it to chess: "One elementary lesson for students of chess is that, in choosing among moves, one can do worse than to count the number of squares dominated by each choice. Generally, the more squares a player dominates, the greater his options and the more constrained become those of his opponent. Similarly, in diplomacy, the more options one side has, the fewer will be available to the other side and the more careful it will have to be in pursuing its objectives. Indeed, such a state of affairs may in time provide an incentive for the adversary to seek to end his adversarial role." See, Diplomacy, p. 719 . Or, as Kissinger put it elsewhere, "the demonstration of options is almost always an asset." See, White House Years, p. 725. He echoed this in his interview with Harvard's American Secretaries of State Project, when discussing the triangular relationship he devised between the United States, Soviet Union and China: "the mere existence of these American options gave us a bargaining weapon." See, SOSP interview, p. 4.

67 White House Years, p. 160.

68 Kissinger uses the term "stake" on a number of occasions when discussing the dynamics of combining pressure and incentives in devising détente with the Soviet Union and rapprochement with China. For example, see Diplomacy, p. 714, 740, and White House Years, p. 192, 1164-5, 1200.

Kissinger remained on guard against permitting the U.S. interest in détente and rapprochement to be used by Moscow and Beijing as levers to rein in American policy in Vietnam. America would not "permit itself to become emotionally dependent on relations with the Soviet Union." See, Diplomacy, p. 712.

${ }^{69}$ White House Years, p. 528, 529-34.

${ }^{70}$ For a fuller analysis see, David M. Keithly, Breakthrough in the Ostpolitik: The 1971 Quadripartite Agreement (Boulder and London: Westview Special Studies in International Relations, 1986).

71 White House Years, pp. 529-34, 824.

72 West Germany and USSR (Treaty of Moscow, August 1970); West Germany and Poland (Treaty of Warsaw, December 1970); United States, Soviet Union, France and United Kingdom (Four Power Agreement, September 1971); United States, Soviet Union, France and United Kingdom (Transit Agreement, May 1972); West Germany and East Germany (Basic Treaty, December 1972); West Germany and Czechoslovakia (Treaty of Prague, December 1973). See, "Germany, a Country Study," Federal Research Division, p. 107. Library of Congress, 1996, http://usa.usembassy.de/etexts/ga5-710903.htm. 
${ }^{73}$ Diplomacy, p. 737. Also see, White House Years, p. 533. Initially skeptical of Brandt's initiative, Nixon and Kissinger came to see his diplomacy as advantageous by linking Brandt's negotiations to the separate U.S.-Soviet negotiations over Berlin (see, White House Years, pp. 530 - 534), as well as creating additional linkage with Soviet policy in Vietnam. Kissinger wrote: "Nixon and his advisers...came to accept Ostpolitik as necessary even while they believed that Brandt-unlike Adenauer-never had an emotional attachment to the Atlantic Alliance." See, Diplomacy, p. 735.

${ }^{74}$ White House Years, p. 1114, 1150.

75 White House Years, p. 1117.

${ }^{76}$ White House Years, p. 1120.

77 Walter Isaacson, Kissinger: A Biography (New York: Simon \& Schuster, 1992), p. 422.

Anatoly Dobrynin provides additional evidence on the Soviet decision not to cancel the 1972 Moscow Summit in view of the mining and bombing of Haiphong Harbor: "the agreements with the Federal Republic of Germany were to be ratified several days before Nixon's arrival, and a cancellation of the summit could exacerbate relations and block ratification, giving weight to the arguments to the ultra right in West Germany who opposed the agreements. Moscow was fully aware of this. Moreover, it also realized that refusing to receive Nixon would complicate our relations with the American administration for a long period, putting off the summit indefinitely, jeopardizing the ABM and SALT agreements, and promoting another round of the arms race." See, Anatoly Dobrynin, In Confidence: Moscow's Ambassador to America's Six Cold War Presidents (1962 - 1986) (New York: Random House, 1995), p. 248.

${ }^{78}$ White House Years, p. 1145.

79 The U.S. policy towards Moscow was to persuade the Soviets at least to stay neutral in Vietnam by ceasing criticism of the U.S. policy, thus giving Washington a "free hand" to pursue the coercive negotiations, while protecting the broader détente from damage. In the following quotes - especially, the first one on p. 1135-from White House Years (1979), Kissinger lays out this logic very explicitly by specifying the limits of Soviet influence and the purposes that he sought the Soviets to serve in the Vietnam negotiations:

p. 1135: "I was convinced that negotiations were inevitable once Hanoi's offensive was blunted. On the other hand, I did not think Moscow could halt the war by ukase, or be expected to turn openly against its ally. The dedicated revolutionaries in Hanoi had fought all their lives; by now they had accumulated enough supplies to see the offensive through regardless of pressures from Moscow. They had staked the war's outcome on its success; it was now too late for Moscow to order them to stop. It was up to the South Vietnamese - and the United States - to take the steps necessary to defeat it. Moscow could not act as our surrogate, though its acquiescence in our reaction would ease our job" (emphasis added).

p. 1177: "For a month I had been pursuing a strategy of seeking Soviet acquiescence in our military moves by enhancing the prospect of a successful summit; after nursing matters to this point it made no sense to refuse even to test the efficacy of what we had labored so hard over" (emphasis added).

p. 1190: "Every statement was part of an effort to persuade Moscow and Peking to acquiesce in our course and thus to move Hanoi, by isolating it, to meaningful negotiations" (emphasis added).

p. 1201: "Our strategy of détente - posing risks and dangling benefits before the Soviets - made possible an unfettered attempt to bring our involvement in the Vietnam war to an honorable close" (emphasis added).

80 Tad Szulc, “How Kissinger Did It: Behind the Vietnam Cease-Fire Agreement,” Foreign Policy, Summer, 1974, pp. 36-37.

There were two types of "communist" forces in South Vietnam: first, Vietcong insurgents, directed by Hanoi since May 1959, and, second, regular North Vietnamese troops first deployed in September 1964. Kissinger first raised the issue for mutual (U.S.North Vietnamese) withdrawal from South Vietnam during his April 4, 1970 meeting with Le Duc Tho.

It was understood that the Vietcong would remain within South Vietnam, whose government would have to confront it. As early as September 1965, Kissinger noted that the "only outcome is limited one...in which VC have some kind of role." In any event, Kissinger assessed that "in many areas government survives only by means of a tacit agreement with the Vietcong whereby both sides coexist without getting into each other's way." See, Niall Ferguson, Kissinger, Volume 1: The Idealist (New York: Penguin, 2015), p. 683, 663. "In some areas the civil government was in cahoots with the Vietcong," Kissinger pointedly observed. See, Niall Ferguson, Kissinger, Volume 1: The Idealist (New York: Penguin, 2015), p. 668. 
How could Kissinger justify leaving North Vietnamese forces intact within South Vietnam (White House Years, p. 1354)? One possible explanation: the communist forces would dwindle by "attrition." "Hanoi was accepting our own compromise formula prohibiting any further infiltration of personnel. This would gradually eliminate North Vietnamese forces in the South through attrition, assuming that the provisions were observed by Hanoi or enforced by us. (That caveat applied to the entire agreement; if doubts as to compliance were to be allowed to block a satisfactory agreement, then the war could never come to a negotiated end; it would have to be fought to the finish.)" See, White House Years, p. 1354, 1373. Yet, Kissinger recognized these were "dangerous waters" and Saigon was "vulnerable." See, White House Years, p. 1317. In 1969, he wrote that "the introduction of communist military forces into the chief bastion of governmental strength would change the balance of political forces in South Viet Nam. The danger of a coalition government is that it would decouple the noncommunist elements from effective control over their armed forces and police, leaving them unable to defend themselves adequately." Henry Kissinger, "The Viet Nam Negotiations," Foreign Affairs, January 1, 1969.

Second possible explanation: some communist presence was an irreversible fait accompli. Tad Szulc argues that Kissinger had been convinced since early 1970 that the North Vietnamese could not be forced to withdraw their regular troops. See, Tad Szulc, "How Kissinger Did It: Behind the Vietnam Cease-Fire Agreement," Foreign Policy, Summer, 1974, p. 41.

${ }^{81}$ White House Years, p. 1189.

82 Tad Szulc, “How Kissinger Did It: Behind the Vietnam Cease-Fire Agreement,” Foreign Policy, Summer, 1974, p. 40.

83 Joseph A. Fry, “Unpopular Messengers: Student Opposition to the Vietnam War.” In David L. Anderson and John Ernst, eds., The War That Never Ends: New Perspectives on the Vietnam War (Lexington, KY: The University Press of Kentucky, 2007), p. 238.

84 For example, Marvin and Bernard Kalb offered a positive assessment: “On June 15 [1972], President [Nikolai] Podgorny flew to Hanoi. The North Vietnamese, feeling betrayed by Russia's hospitality to Nixon, were nevertheless dependent on Moscow as the chief supplier of their war materiel, and they listened carefully to Podgorny's message. It was simple but fundamental: he suggested it was time to switch tactics, time for serious negotiations with the United States. The risk, he argued, would not be critical; after all, Nixon seemed serious about withdrawing, and the new U.S. position no longer demanded a North Vietnamese troop pullout from the south.... It was a new vocabulary for the Russians - the first time they had so openly committed their prestige to a resumption of negotiations. It clearly reflected the Soviet conclusion that the advantages of dealing with Washington on such matters as trade, credits, and SALT were important enough for Moscow to lend Nixon a hand in settling the Vietnam war." Marvin L. Kalb and Bernard Kalb, Kissinger (Boston: Little, Brown, 1974), 336-37. By contrast, Alistair Horne in his generally admiring account of Kissinger's diplomacy, indicated that "Both Nixon and Kissinger placed great hope in using their opening to China as well as détente with Moscow, to put pressure on North Vietnam ... As far as Vietnam was concerned, however, the success with either of these communist behemoths was sorely limited - the line being from Moscow and Beijing: 'we won't interfere with Vietnam's affairs;' though the flow of Soviet arms was reduced." See, Horne, Kissinger: 1973, the Crucial Year (New York: Simon \& Schuster, 2009), p. 155. Winston Lord, who was directly involved in the negotiations with China, the Soviets, and the North Vietnamese observed that "we thought that by our dealing with both giants in the Communist world we would have some psychological impact on Hanoi. This showed Hanoi that Moscow and Beijing cared more about their bilateral relations with the U.S. than they did about their relations with Hanoi. They wouldn't snub Hanoi, but psychologically this would help to isolate Hanoi, e.g. holding summits in Beijing and Moscow while we had some of our meetings with Hanoi in the winter and spring of 1972, in the middle of Hanoi's offensive in South Vietnam. Neither Moscow nor Beijing went so far as to cut off aid to North Vietnam or really lean on Hanoi. However, both Moscow and Beijing had a stake in our trying to get the Vietnam War behind us. ... We believed that both Russia and China talked to Hanoi and suggested to North Vietnam that, in its own self-interest, they ought to settle for a military solution. ..." See, "Ambassador Winston Lord interviewed by: Charles Stuart Kennedy and Nancy Bernkopf Tucker," Association for Diplomatic Studies and Training Foreign Affairs Oral History Project. Initial interview date: April 28, 1998, p. 271.

85 Nixon and Kissinger originally raised the possibility of high-level U.S.-North Vietnam contacts with Thieu during a meeting at Midway Island in the Pacific on June 8, 1969. "Thieu agreed," Kissinger remembered, "provided he was informed about any political discussions." See, White House Years, p. 274. Al Haig, Kissinger's military aide, also briefed Thieu on July 3, 1972. See, White House Years, p. 1310.

While keeping Thieu generally informed, Kissinger's preference clearly was to keep Thieu away from the specifics of the negotiation because of the need to dissociate the military (withdrawal) and political (structure of South Vietnamese government) aspects of the negotiation. Writing in 1969, Kissinger stated: "The United States...should concentrate on the subject of the mutual withdrawal of external forces and avoid negotiating about the internal structure of South Viet Nam for as long as possible. ...The participation of Saigon and the NLF [in earlier negotiations] raised issues...that would have been better deferred; it made discussion of the internal structure of South Viet Nam hard to avoid." Henry Kissinger, "The Viet Nam Negotiations," Foreign Affairs, January 1, 1969.

${ }^{86}$ White House Years, p. 1319, 1327. 
87 White House Years, p. 1345 and, also, see p. 1317.

${ }^{88}$ Kissinger reflected: "And I turned to Winston [Lord] and said 'we've done it' and shook hands with him. So it was a great moment." See, SOSP interview, p. 8. However, this was strictly a private reaction: "negotiators must not betray emotion; it becomes a weapon in the hands of the other side." See, White House Years, digital edition, p. 659. Furthermore, as the negotiations were nearing conclusion in January 1973, Kissinger confided in Nixon: "The slightest hint of eagerness could prove suicidal." See, White House Years, p. 1464, and also p. 438, on the dangers of giving an "unnecessary impression of eagerness" in a negotiation.

89 The threats were communicated on October 22, 24, 28, November 10, 29, December 17, 1972, and January 5, 16, 17 and 20, 1973. See, White House Years, p. 1382, 1396, 1402, 1412, 1426, 1459, 1462, 1469 - 1470.

90 The assurances were communicated on October 19, 24, 28, November 14, 29, 1972, and January 5, 14 and 21, 1973. See, White House Years, p. 1369, 1396, 1402, 1412, 1426, 1462, 1470. "American air power was thus always seen as an essential deterrent to the resumption of all-out war. Nixon gave assurances on this score to South Vietnamese President Nguyen Van Thieu to persuade Thieu to accept the Paris Agreement." Henry Kissinger, Years of Upheaval (New York: Simon \& Schuster, 1982), p. 303.

${ }^{91}$ SOSP interview, p. 11.

92 SOSP interview, p. 11. Douglas Brinkley quotes Kissinger aide John Negroponte as admitting (in Michael Maclear's TV series Vietnam: The Ten Thousand Day War [1980-1981]) that "The peace treaty did nothing for Saigon. We got our prisoners back; we were able to end our direct military involvement. But there were no ostensible benefits for Saigon to justify all of the enormous effort and bloodshed of the previous years." See, Douglas Brinkley, Tour of Duty: John Kerry and the Vietnam War (New York: William Morrow, 2004), p. 426. When considering such statements, it is important to keep in mind the difference between ex ante objectives (Kissinger's expectation that the agreement would be enforced) and ex post assessments (Negroponte's statement).

93 White House Years, p. 1411.

94 This was the same situation as before 1968 when, as Clark Clifford, Lyndon Johnson's Secretary of Defense said, “The South Vietnamese did not want to end the war-not while they were protected by over five hundred thousand American troops and a gold flow of money." Quoted in Douglas Brinkley, Tour of Duty: John Kerry and the Vietnam War (New York: William Morrow, 2004), p. 131. Or, as Kissinger assessed during his own negotiations with Thieu in 1972, the South Vietnamese "were not satisfied with survival; they wanted a guarantee that they would prevail." See, White House Years, pp. 1323-1324. Yet, this stood in direct opposition to the U.S. objectives: "We had to fight the war and simultaneously strengthen the South Vietnamese to survive without us - in other words, to make ourselves dispensable." See, White House Years, p. 232. Indeed, Kissinger argued, "we had no duty to them to guarantee them a total victory that we were unable to define, whose achievement required an open-ended commitment extending over many years more, and that we had publicly forsworn for the past three years." See, White House Years, p. 1349.

In the following passages, Kissinger reflects on the barriers to a negotiated agreement between the two Vietnams, and the cultural differences that prevented the United States from promptly grasping the seriousness of these obstacles: "Our constant search for some compromise formula illuminated the cultural gap between us and the Vietnamese because the very concept of compromise was alien to both Vietnamese parties.

We had no way of understanding the primeval hatred that animated the two sides. They had fought each other for a generation. They had assassinated each other's officials, tortured each other's prisoners. The chasm of distrust and mutually inflicted suffering was unbridgeable by goodwill or the sort of compromise formulas toward which Americans incline. Each Vietnamese party saw in a settlement the starting point of a new struggle sometime in the not too distant future. Every deliberately vague formula I put forward was tested by each side to determine to what extent it represented an opportunity to inflict a humiliation on the despised opponent. And both sides were marvelously subtle and ingenious in changing phraseology to score such victories, particularly in the Vietnamese language with its finely shaded meanings quite beyond our grasp." See, White House Years, p. 1325. Likewise, Kissinger observed succinctly elsewhere, the North Vietnamese "had not fought for forty years to achieve a compromise." See, White House Years, p. 259, 1367.

95 White House Years, pp. 1416 - 1422, $1428-1443$.

96 "I had come to Paris on December 4 with instructions from Nixon to settle. Le Duc Tho had kept me there ten days, our longest negotiating session ever, and each day we seemed farther away from an agreement. ... Each day several issues that we thought had been settled in the agreement emerged again in loaded North Vietnamese drafts of either the understandings

Copyright 2016 (C) James K. Sebenius 


\section{Henry A. Kissinger as Negotiator}

or the protocols. Le Duc Tho would then yield on most of these in a long day of negotiation, but made sure that enough were left over, or new ones reopened, to prevent a conclusion.... This was the insoluble problem over which we began the Christmas bombing five days later." See, White House Years, pp. 1444-1445.

${ }^{97}$ White House Years, p. 1448, 1459. The destructive capacity of this bombing campaign - called Operational Linebacker II - was larger than that of all of the bombs used against North Vietnam from 1969 to 1971. At the time, Vietnam veteran John Kerry was "flabbergasted" (in the words of historian Douglas Brinkley) by the "monstrous brutality" of the bombing campaign, and Senate Majority Leader Mike Mansfield called the attacks a "Stone Age tactic." See, Douglas Brinkley, Tour of Duty: John Kerry and the Vietnam War (New York: William Morrow, 2004), pp. 425-428.

98 White House Years, p. 1463. Douglas Brinkley agrees that the "Christmas bombings had worked" in forcing Hanoi to negotiate. See, Douglas Brinkley, Tour of Duty: John Kerry and the Vietnam War (New York: William Morrow, 2004), p. 427.

${ }^{99}$ White House Years, pp. 1469 - 1470.

100 SOSP interview, p. 11.

101 SOSP interview, p. 11.

102 Diplomacy, p. 696

103 Years of Upheaval, p. 327. In addition, Kissinger notes, "I was fighting a desperate but losing struggle against the Pentagon's desire to redeploy air and naval forces out of Southeast Asia in order to devote scarce funds to the procurement of new weapons." See, Years of Upheaval, p. 329.

104 Years of Renewal, p. 546.

105 Alistair Horne, “The Case for Henry Kissinger,” The Independent, August 18, 2009, http://www.independent.co.uk/news/world/americas/the-case-for-henry-kissinger-1773365.html.

106 SOSP interview, p. 12. 